\title{
Aborto no Congresso Nacional: o enfrentamento de atores religiosos e feministas em um Estado laico
}

Abortion in National Congress: the struggle between feminists and religious actors in a laic State

O artigo analisa a partir da antropologia o debate sobre aborto na Câmara dos Deputados durante as duas legislaturas do governo Lula (2003-2006; 2007-2010) considerando o embate entre as posições pró-vida e pró-escolha. Trata-se da análise de uma controvérsia pública, o que vai permitir verificar os argumentos e estratégias dos principais atores envolvidos, suas normas e valores (Giumbelli, 2002) ${ }^{1}$. No exame da discussão sobre o aborto na esfera principal do poder legislativo federal, ao considerar os valores e atores envolvidos, destaca-se a presença de religiosos que vários estudos costumam identificar automaticamente com a posição pró-vida (Rostagnol, 2008; Rocha, Rostagnol e Gutierrez, 2009). A posição pró-escolha aparece entre representantes do movimento feminista e parlamentares sensíveis às demandas dos movimentos de mulheres (cf. Machado, 2010). A presença tão destacada de atores religiosos no debate público sobre o aborto insere este artigo no estudo da religião no espaço público com os temas associados da secularização e da laicidade (Giumbelli, 2002; Montero, 2009). Nesse sentido, a investigação está conectada também aos estudos sobre a inserção de religiosos na política recente do país, tanto os

\footnotetext{
É professora do Programa de Pós-graduação em Ciências Sociais e do Departamento de Ciências Sociais da UFRRJ (Seropédica, RJ, Brasil).E-mail: naara_luna@ig.com.br.

Segundo Giumbelli (2002), a observação de controvérsias públicas constituídas em torno de grupos religiosos permite analisar os argumentos e estratégias dos principais atores envolvidos. As controvérsias constituem um revelador privilegiado para padrões, normas, valores vigentes nas sociedades que abrigam esses grupos. Aparatos estatais, o que inclui questões legais, e o universo da mídia são outros personagens relevantes nas controvérsias.
} 
que assumem cargos executivos e parlamentares (Machado, 2006, Campos, 2006) como o das instituições religiosas (Oro, 2003). Em continuidade com a pesquisa "Valores religiosos e legislação no Brasil" (Duarte et al.., 2009), o presente artigo mostra uma visão mais matizada das posições em torno do aborto, ao identificar diversidade no campo de várias formas: com respeito ao grau de adesão ao discurso pró-vida por parte de religiosos; no tocante à presença de religiosos entre os que advogam a posição pró-escolha; bem como de posicionamentos claros pró-vida vindos de atores sem religião identificada.

Os estudos sobre religião e política referentes ao início dos anos 2000 marcam uma ascensão e visibilidade de grupos religiosos no poder, em particular o crescimento da bancada evangélica. No tocante ao debate sobre o aborto no legislativo federal, Rocha e Adalaft Neto (2003) identificam no final dos anos 1990 o crescimento das posições pró-vida e um pequeno recuo da presença das reivindicações feministas. Com respeito à filiação religiosa na sociedade mais ampla, no período sob exame destacam-se a redução da proporção de católicos no Brasil e o crescimento dos evangélicos, em particular dos grupos pentecostais e neopentecostais (cf. Jacob et al.. 2003). Entre os censos de 2000 e 2010, houve redução da população católica da ordem de $73,9 \%$ para $64,9 \%$ (tendência já prevista no Atlas da filiação religiosa) e aumento do número dos sem religião. ${ }^{2}$

Ainda no âmbito do catolicismo no Brasil, no período acentua-se a predominância dos grupos ligados à orientação mais conservadora do Vaticano, há o crescimento da Renovação Carismática Católica - que, em termos morais, também tende ao conservadorismo - e reduz-se a presença dos católicos ligados às pastorais populares e à Teologia da Libertação, conforme descrevem Birman e Leite (2002). A ênfase dos pentecostais em uma identidade marcada pelo rigorismo moral com respeito à família e sexualidade (Machado, 2000) se explicita no Congresso com a criação da Frente Parlamentar Evangélica em 2003 (o primeiro ano do material aqui investigado). Por outro lado, reconhece-se orientação mais modernizante por conta da Igreja Universal do Reino de Deus (IURD) no tocante ao uso de contracepção para manter a prosperidade material da família (cf. Gomes, 2009). No contexto do campo

\footnotetext{
"O período de 1980 a 2000 se caracteriza por um amplo movimento de diversificação religiosa, ligado à redução do numero de cat6licos (-15,1 pontos percentuais), a um forte aumento do numero de evangélicos (+9 pontos), principalmente dos pentecostais, e a um expressivo crescimento das pessoas sem religião (+5,8pontos)" (Jacob et al., 2003, p. 33).
} 
religioso brasileiro, existe rivalidade entre a Igreja Católica e as evangélicas, com ocorrência de críticas e competição por parte das neopentecostais como a Igreja Universal do Reino de Deus (Machado, 2000). A análise do debate legislativo adiante vai verificar se tal divergência se mantém.

No período anterior ao governo Lula, constata-se forte apoio dos setores da Igreja Católica ligados à Teologia da Libertação e das pastorais populares ao Partido dos Trabalhadores (PT). Tais movimentos apresentam uma agenda relacionada aos direitos humanos, com ênfase nos direitos políticos e sociais (Leite, 2003). Com a chegada de Lula ao governo, no período contemplado pelas duas legislaturas sob exame, ocorrem divergências entre a agenda do governo em algumas ocasiões. Destacam-se alguns momentos críticos: 1) a aprovação no Congresso Nacional em 2005, com sanção do presidente Lula, da Lei de Biossegurança, que autorizou a extração de células-tronco embrionárias de embriões restantes de reprodução assistida e decorrente ação no Supremo Tribunal Federal julgada em 2008; 2) a posição do ministro da Saúde José Gomes Temporão que coloca o aborto como problema de saúde pública e defende sua descriminalização em 2007; 3 ) a proposta do 3o Programa Nacional de Direitos Humanos (PNDH3), em dezembro de 2009, debatida em 2010, de apresentar projeto legislativo que descriminaliza o aborto, "considerando a autonomia das mulheres para decidir sobre seus corpos" (Luna, 2010). Esses tópicos serão temas de discursos no plenário do Congresso Nacional. A atualização dessa agenda de direitos humanos por parte dos parlamentares será examinada também a partir dos discursos e proposições legislativas referentes ao aborto apresentadas.

O material sob exame são os discursos e proposições legislativas no período. O texto apresenta separadamente as duas legislaturas. O levantamento dos projetos de lei e discursos foi realizado no portal da Câmara dos Deputados (www.camara.gov.br) utilizando o mecanismo de busca disponível em "projetos de lei e outras proposições" e "discursos e notas taquigráficas". Os temas que incitaram os debates no plenário da Câmara foram objeto de pesquisa. ${ }^{3}$ Os discursos são classificados na orientação antiaborto (pró-vida) e pró-escolha, mas há um número significativo de pronunciamentos indefinidos, que não se encaixam em nenhuma classificação. Devido ao grande número de proposições legislativas, serão analisados aqui apenas os projetos de lei.

Agradeço a meu assistente de pesquisa Felipe Guimarães Lamim, que, sob minha orientação, fez o levantamento das proposições legislativas e dos discursos e iniciou a classificação. 
Buscou-se identificar a religião dos deputados federais que pronunciaram discursos na Câmara, ou que apresentaram projetos de lei ou outras proposições contendo as palavras-chave aborto, nascituro e embrião nas legislaturas de 2003-2006 e 2007-2010, ${ }^{4}$ ou seja, durante os dois mandatos do governo Lula. As fontes mais usadas foram os registros da Frente Parlamentar Evangélica e da Pastoral Parlamentar Católica, bem como a autodeclaração de pertencimento religioso dos parlamentares em seus discursos, com consulta da biografia dos parlamentares disponível no portal da Câmara dos Deputados, embora se tenha recorrido esporadicamente a mecanismos de busca na internet. ${ }^{5}$ A classificação "sem religião identificada" é residual: significa que não foi possível encontrar vínculo religioso nas fontes disponíveis. Isso é um problema no caso dos parlamentares católicos no Brasil, onde a maioria da população se diz católica não praticante. Não se encontraram listas de parlamentares espíritas e de religiões de matriz africana ${ }^{6}$ ou de outros credos religiosos, o que atesta os limites deste artigo a parlamentares cristãos. Foram verificados todos os parlamentares autores de discursos, projetos de lei e outras proposições legislativas contendo as palavras-chave. Este primeiro exame sugere o grande envolvimento de parlamentares religiosos no debate. Nem sempre é possível classificar um projeto ou discurso como de orientação pró-vida ou pró-escolha.

\section{Análise dos temas dos discursos e proposições legislativas: Câmara dos Deputados (2003-2006)}

Na legislatura de 2003-2006, na Câmara dos Deputados, foram proferidos 278 discursos com as palavras-chave aborto, embrião e nascituro. Pouco menos da metade dos discursos (136, ou 49\%) trazia a palavra "aborto" e uma proporção ligeiramente menor (131, ou 47,2\%) trazia a palavra "embrião", enquanto "nascituro" apareceu em 10 (3,6\%). Em relação a outras legislatu-

\footnotetext{
O levantamento originalmente considerou as palavras-chave:"aborto," "nascituro","embrião," "reprodução assistida"e "fertilização in vitro". Para os propósitos de análise deste artigo, o foco serão as palavras "aborto"e "nascituro", aludindo-se ao termo "embrião" se o contexto exigir.

Agradeço a Benedito Dias, funcionário da Frente Parlamentar Evangélica, e a Marcelo Lopes da Ponte, assessor do gabinete do deputado José Linhares, coordenador da Pastoral Parlamentar Católica, pelas listas de participantes enviadas.

- O único parlamentar identificado como espírita pertence ao espiritismo kardecista. Em algumas classificações, religiões de matriz africana como a umbanda e o candomblé são agrupadas entre os espíritas, mas o presente artigo refere-se apenas ao espiritismo kardecista, por não haver detectado parlamentares de outras religiões.
} 
ras, a proporção de menções à palavra "embrião" é a mais alta encontrada, em função do debate legislativo da Lei de Biossegurança (do fim de 2003 ao início de 2005), que versava entre outros temas sobre a autorização da pesquisa com células-tronco embrionárias. Quanto aos discursos referentes a aborto: os temas mais frequentes foram a alteração da norma técnica "Atenção humanizada ao abortamento", publicada pelo Ministério da Saúde em 2005, que dispensou a apresentação do boletim de ocorrência para realização de aborto em caso de estupro nos serviços de aborto legal. ${ }^{7}$ Foi debatida a formação de comissão tripartite por iniciativa do Executivo, com o objetivo de revisar a legislação punitiva sobre o aborto, composta de 18 membros, sendo seis do Executivo, seis do Legislativo e seis da sociedade civil (esse processo ocorreu nos anos de 2005 e 2006). Outro ponto de destaque nos debates em 2004 diz respeito ao Supremo Tribunal Federal (STF): a concessão de liminar pelo ministro Marco Aurélio Mello autorizando o aborto quando comprovada a gestação de anencéfalo. A Arguição de Descumprimento de Preceito Fundamental 54 (ADPF 54) foi proposta pela Confederação Nacional dos Trabalhadores da Saúde, pleiteando autorizar a antecipação de parto em caso de diagnóstico comprovado de anencefalia, sem necessidade de outra permissão judicial para a gestante ou para o médico. A liminar foi derrubada pelo plenário do Supremo após quatro meses, mas foi acolhido o mérito da ação para a ADPF 54 ser julgada no futuro.

Em 2003, cinco deputados fizeram discursos com a palavra-chave "aborto", sendo três de orientação antiaborto, um de orientação pró-escolha, e um neutro. Todos os três discursos de orientação antiaborto foram proferidos por religiosos: dois católicos (Elimar Máximo Damasceno, do Partido da Reedificação da Ordem Nacional - PRONA-SP - e Severino Cavalcanti, do Partido Progressista Brasileiro - PPB-PE) e um evangélico da Assembleia de Deus (Costa Ferreira, do Partido da Frente Liberal - PFL-MA). O discurso pró-escolha foi proferido por uma deputada sem religião identificada (Fátima Bezerra, PT-RN). O discurso indefinido partiu de uma deputada católica. ${ }^{8}$

No Brasil, o artigo 128, do Código Penal, datado de 1940, não prevê a punição para o aborto apenas em dois casos: aborto necessário (quando não há outro meio de salvar a vida da gestante) e no caso de gravidez resultante de estupro.

8 Foram classificados como indefinidos: os discursos que mostravam dois lados do problema do aborto sem tomar partido, o que incluiu denúncias da prática sem se pronunciar contra ou a favor da legalização, os que simplesmente diziam que o assunto deveria ser discutido, ou os que levavam encaminhamentos burocráticos de terceiros (ex. integrante da mesa da Câmara lê proposta de outro). 
Destaca-se a atuação do parlamentar Elimar Máximo Damasceno, que proferiu oito discursos com a palavra "aborto" e um com a palavra "nascituro".

Em 2004, houve 35 deputados que discursaram sobre o aborto. Destes, 25 tiveram posição antiaborto, quatro foram pró-escolha, cinco admitiram o aborto em caso de anencefalia, e em um discurso a menção a aborto não fazia referência a posição pró-escolha ou pró-vida. Dos discursos antiaborto, quinze foram proferidos por evangélicos; ${ }^{9}$ nove por católicos e um por um deputado sem religião identificada. Os quatro discursos pró-escolha foram proferidos por deputados sem religião identificada, enquanto dos cinco discursos pró-escolha em caso de anencefalia quatro foram de evangélicos ${ }^{10}$ e um de deputado sem religião identificada. $O$ único pronunciamento indefinido foi de autoria de deputado sem religião identificada. Essa contagem sugere uma forte associação de religiosos com a posição antiaborto, mas revela certos matizes, como a admissão do aborto em caso de anencefalia por três evangélicos de igrejas do pentecostalismo de terceira onda e por um do protestantismo histórico de missão. Por outro lado, os identificados católicos concentram-se na posição antiaborto, encontrando-se apenas um indefinido. Destaca-se novamente pelo número de discursos com a palavra-chave "aborto" o deputado católico Elimar Damasceno (PRONA-SP), com seis em plenário.

Retomo aqui o debate despertado pela ADPF 54, que autoriza a antecipação de parto de anencéfalo. Em 2004 foram realizados 32 discursos em plenário com a temática do aborto. O principal acontecimento norteador desses discursos foi a liminar concedida pelo então ministro do STF Marco Aurélio Mello, que autorizava o aborto em caso de anencefalia. Oito parlamentares apoiaram e defenderam em plenário a atitude do ministro do Supremo, dentre eles os membros da bancada evangélica: pastor João Batista (PFL-SP) e José Divino (Partido do Movimento Democrático Brasileiro - PMDB-RJ), ambos da IURD; e Neucimar (Partido Liberal - PL-ES), da Igreja Batista. Esses parlamentares justificaram a posição pró-escolha em caso de gestação de feto anencefálico comparando o embrião sem cérebro à situação de morte

Foram dez da Assembleia de Deus, dois do Evangelho Quadrangular, um da Igreja Universal do Reino de Deus, um da Comunidade Shamá e um batista.

10 Eram dois da IURD, um da Igreja Internacional da Graça de Deus e um batista. A Assembleia de Deus e a Igreja do Evangelho Quadrangular pertencem ao pentecostalismo clássico, a IURD e a Igreja da Graça são os protótipos do modelo neopentecostal. Os batistas provêm do protestantismo histórico de missão. Sobre evangélicos no Brasil, cf. Mafra (2001) e Freston (1996). 
cerebral. A partir dessa analogia, dizem que o sofrimento da mãe seria vão, já que o filho não teria chances de sobrevivência e que essa interrupção não consistiria em aborto posto que o embrião sem cérebro, tal como a pessoa que sofre a morte encefálica, não possuiria expectativa de sobrevida. Os deputados João Batista e José Divino, apesar de enfatizarem nos discursos o pertencimento religioso evangélico, salientam a importância do Estado laico, da Constituição Federal e do avanço da medicina ao argumentarem sobre anencefalia.

Os outros parlamentares que se posicionaram a favor da liminar do ministro Marco Aurélio foram: Luciana Genro (sem partido-RS); Dr. Pinotti (PFL-SP); Almir Moura (PL-RJ), evangélico da Igreja Internacional da Graça de Deus; Roberto Gouveia (PT-SP); e Jandira Feghali (PCdoB-RJ). Luciana Genro chamou de "decisão retrógada" a cassação da liminar que autorizava a interrupção da gravidez em caso de anencefalia. Dr. Pinotti ressaltou que a morte cerebral determina a vida, e também fez uma analogia entre morte encefálica e anencefalia. Roberto Gouveia salientou que a falta de expectativa de vida nos casos de anencefalia não faria da interrupção uma prática de abortamento. Apenas Jandira Feghali citou a religião ao chamar de absurda a proibição da interrupção da gravidez em caso de anencefalia, que seria sustentada por argumentos religiosos.

Foram nove os parlamentares que se pronunciaram em plenário contra a liminar que autorizava a interrupção da gravidez em caso de feto anencefálico: Elimar Damasceno e Enéias (ambos do PRONA-SP, católicos) procuraram legitimar seus argumentos posicionando-se como médicos e usando também de jargão técnico. Além disso, reforçaram que deveria ser respeitado o direito incondicional à vida desde a fecundação. Chamaram de eugenia a interrupção da gravidez de anencéfalo, e disseram que essa prática criaria seres privilegiados na sociedade. Para o deputado Elimar Damasceno a ausência de cérebro não justificaria o aborto e a breve existência do anencéfalo representaria sua vida, que não poderia ser "descartada como coisa". Segundo o parlamentar, a decisão da mulher de abortar o feto anencefálico seria influenciada pela "angústia da notícia de grave anomalia".

As questões que apareceram nos discursos contra a liminar do STF foram: 1) possibilidade de salvar a vida de outros bebês a partir de transplantes (Angela Guadanin, PT-SP, católica); 2) direito incondicional à vida desde a fecundação; 3 ) prática de aborto de fetos anencefálicos vista como 
"homicídio" (Osmânio Pereira, Partido Trabalhista Brasileiro - PTB-MG, católico), "banalização da vida", "barbárie legalizada" (Costa Ferreira, Partido Social Cristão - PSC-MA, evangélico, da Assembleia de Deus), "ideologia nazista", "controle populacional", "eugenia", "criação de seres superiores e inferiores" (Severino Cavalcante, Partido Progressista - PP-PE, católico); 4) denominação do promotor Diaulas Ribeiro como "serial killer"11 e das feministas como "neo-eugenistas"; 5) medo de que o aborto de fetos anencefálicos leve ao irrestrito aborto de fetos com quaisquer más-formações congênitas; 6) conceito de vida presente no anencéfalo mesmo com ausência de cérebro, e até nos casos de morte encefálica ${ }^{12}$; 6) inconstitucionalidade da liminar do ministro Marco Aurélio, posto que o Código Penal brasileiro só permite a prática do aborto em caso de estupro e risco de morte para a mãe; 7) usurpação da função de fazer leis do Poder Legislativo pelo poder Judiciário (Milton Cardias, PTB-RS, evangélico da Assembleia de Deus); 8) importância dos argumentos religiosos tal como dos jurídicos e científicos, possuindo todos relevância na discussão sobre a vida (Salvador Zimbaldi, PTB-SP, católico).

Em 2005, houve um número menor de parlamentares a se colocar sobre o aborto - um total de 25 -, talvez porque o tema da pesquisa com células-tronco embrionárias humanas tenha ocupado muito espaço no plenário. Desses 25 deputados, vinte eram antiaborto, três fizeram pronunciamentos indefinidos e dois eram pró-escolha. Dos 19 com posição antiaborto, nove eram evangélicos, ${ }^{13}$ oito católicos, dois sem religião identificada, e um espírita. As duas parlamentares que se pronunciaram pró-escolha são sem religião. Dos três que fizeram pronunciamentos de posição indefinida, dois eram católicos e um era evangélico (da IURD). Em 2005, destacam-se os seguintes deputados pelo número de discursos: Adelor Vieira (PMDB-SC), evangélico da Assembleia de Deus com oito; o católico Elimar Damasceno (PRONA-SP) com nove, e o espírita Luiz Bassuma (PT-BA) com nove, os três com discursos antiaborto, enquanto não houve parlamentar de posição pró-escolha que se aproximasse desses números.

\footnotetext{
1 O promotor Diaulas Ribeiro admitiu ter autorizado 61 abortos em casos de fetos com má-formação em entrevista ao jornal Correio Braziliense, da capital federal.

12 Para Arlindo Chinaglia (PT-SP) "sob o impacto de uma dor imensa, (a família) acaba ouvindo dos médicos que assistem ao ente querido que o fato de o coração bater não significa vida. Se assim não fosse, em muitos casos, os transplantes não seriam viáveis". (discurso: 20 de outubro de 2004)

13 Foram sete da Assembleia de Deus, um da IURD e um batista.
} 
Em 2006, foram localizados 11 deputados que discursaram mencionando a palavra-chave "aborto" e um citando a palavra-chave "nascituro". Desses, sete apresentavam posição antiaborto e cinco, posição pró-escolha. A posição antiaborto estava presente nos discursos de quatro deputados católicos, de dois evangélicos (um da Assembleia de Deus e um batista) e de um espírita. A posição pró-escolha foi manifestada nos pronunciamentos em plenário de quatro deputados sem religião identificada e de uma católica. Destacou-se o deputado Luiz Bassuma (PT-BA) com quatro discursos.

Houve 58 proposições legislativas na legislatura de 2003-2006 na Câmara contendo as palavras-chave, das quais 22 eram projetos de lei. Em sua maioria, os projetos tinham perspectiva antiaborto de variados modos: estabelecendo direitos para o nascituro ou sua proteção (5), definindo o aborto como crime hediondo (2), aplicando pena para aborto eugênico (um), criando uma central de atendimento para denúncias contra o aborto (um), estabelecendo o registro público da gravidez (um), propondo orientação à gestante em decorrência de estupro (um), proibindo a comercialização da pílula do dia seguinte (um), punindo aborto em caso de estupro (um). Um projeto disciplina o funcionamento das clínicas de reprodução humana, e limita a fecundação de óvulos a fim de impedir a redução embrionária (aborto seletivo de embriões). Cinco projetos de lei suprimiam pena ou descriminalizavam o aborto. Os projetos de lei antiaborto têm as seguintes estratégias: aumentar a penalidade ou criar tipo penal (caso do crime hediondo e do aborto eugênico), aumentar o controle social para evitar aborto ou uso de práticas e substâncias consideradas abortivas (central de atendimento para denúncias, registro da gravidez, orientação da gestante em serviço de aborto legal para que leve a gravidez a termo, proibição da pílula do dia seguinte, regulação de clínicas de reprodução humana) e estabelecer direitos ou proteção para o nascituro. De modo geral, não houve parlamentar que se destacasse no tocante apenas à apresentação de projetos de lei, atingindo um ou dois projetos nesse tema no período levantado.

No tocante ao pertencimento religioso, com base nos 14 projetos de inclinação pró-vida (o que inclui antiaborto e a defesa dos direitos do nascituro ou recém-nascido), dos quatro projetos que aumentam a penalidade ou criam tipos penais foram identificados três autores católicos, um espírita e um evangélico (Sara Nossa Terra) ${ }^{14}$, considerando que um projeto tinha

${ }^{14}$ Igreja fundada em Brasília em 1992, também de caráter neopentecostal. Informações no portal: http:// www.saranossaterra.com.br. 
mais de um autor. Os seis projetos voltados para o controle social são de autoria de quatro católicos e dois evangélicos (Assembleia de Deus). Quanto aos cinco projetos de lei que promovem direitos para o nascituro, houve um autor sem religião identificada, quatro católicos e um evangélico (IURD).

O lado pró-escolha traz cinco projetos de lei com propostas de suprimir a pena ou descriminalizar o aborto, e uma proposta de estabelecer direitos para as mulheres vítimas de violência. As propostas de suprimir a pena abrangem: violência contra a mulher, morte ou risco de doença física ou psíquica da mulher, doença congênita incurável no nascituro que traga sofrimento e crime contra a liberdade da mulher, anencefalia (duas). Um dos projetos suprimia ainda o artigo 128 do Código Penal, que criminaliza o aborto. No tocante ao pertencimento religioso, os cinco projetos que propunham a descriminalização do aborto ou supressão de pena eram de 13 autores sem pertencimento religioso identificado e de dois católicos (um dos projetos tinha nove autoras, uma das quais era católica, e outro tinha dois autores). O projeto voltado para direitos das mulheres vítimas de violência era de autora sem pertencimento religioso identificado.

Dois projetos não cabiam na polarização favorável ou contrário ao aborto: ambos versavam sobre a permissão de laqueadura em situação de parto ou aborto, ou seja, não regulamentavam o aborto em si. Um era de autora sem vínculo religioso identificado e outro era de evangélico (IURD).

Considerando a presente análise no campo legislativo, gostaria de destacar dois sujeitos sociais da esfera religiosa que atuam no debate sobre aborto e se fazem presentes nos discursos, além de um valor acionado nesse contexto: a laicidade. A Conferência Nacional dos Bispos do Brasil (CNBB) é citada diversas vezes nos discursos de parlamentares. A ONG Católicas pelo Direito de Decidir também é citada. Um valor que aparece no debate é o da laicidade, com questões sobre o caráter laico do Estado brasileiro. No quadriênio de 2003-2006, a CNBB é citada por nove parlamentares. Os contextos em que é citada: no tocante ao debate sobre a Lei de Biossegurança, especificamente acerca da pesquisa com células-tronco embrionárias (2004 e 2005); sobre a Norma Técnica do Ministério da Saúde que dispensa a apresentação do Boletim de Ocorrência para aborto em caso de estupro (2005); acerca da comissão tripartite de revisão da legislação punitiva sobre o aborto (2005) e em documentos em defesa da vida e contra o aborto (2005); e em marcha contra o aborto (2006) e pela celebração do Dia do Nascituro. Nessa legislatura, a 
CNBB é mencionada apenas por parlamentares que têm posição antiaborto ou contrária à pesquisa com células-tronco embrionárias humanas. Dos nove parlamentares que se referem à $\mathrm{CNBB}$, cinco são católicos, dois são evangélicos (Assembleia de Deus e Comunidade Shamá), um é espírita e um não tem religião identificada. Ambos os evangélicos citam declarações públicas da CNBB como reforço às suas próprias posições: a Frente Parlamentar Evangélica junto com a CNBB em articulação contra as pesquisas com células-tronco embrionárias humanas; e em oposição a projetos que visem à legalização do aborto no país. O deputado espírita faz três discursos contrários ao aborto, mencionando também os evangélicos em um deles, e a articulação da Frente Parlamentar contra o Aborto com a CNBB em mobilizações e atos públicos.

Já a ONG Católicas pelo Direito de Decidir é citada por dois parlamentares, ambos católicos, em termos de crítica por estabelecer um debate sobre gênero e sobre direitos reprodutivos e mais diretamente como inimiga da Igreja Católica por sua luta pela descriminalização do aborto.

Nessa legislatura, o argumento do Estado laico aparece em sete discursos referentes às palavras-chave da pesquisa, sendo quatro de evangélicos (dois assembleianos e dois da IURD), e três de católicos. No pronunciamento de um deputado evangélico (IURD), o Estado laico aparece como justificativa para sua posição favorável à pesquisa com células-tronco embrionárias e ao avanço da medicina, e no de um segundo deputado evangélico, também da IURD, na defesa do aborto em caso de anencefalia. Em todos os demais discursos, o Estado laico é questionado. À tese de que em Estado laico não se deve legislar sob a influência da religião se contrapõem as seguintes expressões: a "tradução em leis do espírito que molda a sociedade"15, a defesa da posição antiaborto como cidadão e não como religioso, a crítica à noção de laico como progressista e a defesa da liberdade de culto, no sentido de que o Estado laico não obriga nem impede a prática religiosa. A defesa do direito à vida não seria representada por esses últimos parlamentares como questão religiosa nos trechos analisados.

\section{Câmara dos Deputados (2007-2010)}

No segundo mandato do governo Lula (2007-2010), foram localizados 361 discursos com as palavras-chave. A pesquisa com a palavra "aborto" foi a

15 Discurso do deputado Osmânio Pereira em 27 de outubro de 2004. 
que encontrou mais resultados: 278 discursos (77\% do total no quadriênio). A busca pela palavra "embrião" totalizou 66 pronunciamentos (18,3\%). O levantamento da palavra "nascituro" revelou 17 discursos (4,7\%). Salienta-se a diminuição significativa da frequência da palavra "embrião", que foi citada em quase metade dos discursos com as palavras-chave na legislatura anterior e é reduzida e menos de um quinto desse montante. Esse aspecto revela a importância do debate da Lei de Biossegurança no quadriênio anterior, debate esse que será retomado na Câmara por ocasião do julgamento no Supremo em 2008. Os acontecimentos que mais suscitaram os discursos foram: clínica de planejamento familiar em Mato Grosso do Sul acusada de realizar aborto ilegal, cujas pacientes foram processadas com base nessa acusação ("quase dez mil mulheres"). Foi objeto de debate o caso da menina de 9 anos em Lagoinha (PE) que engravidou do próprio padrasto e foi encaminhada para fazer aborto, a despeito de pressões contrárias de representantes da Igreja ligados ao movimento. Ainda quanto a esse caso, causou muito impacto a declaração do arcebispo de Olinda à imprensa sobre a excomunhão automática da mãe que autorizou o aborto e da equipe médica. Foi muito citado o caso da menina Marcela de Jesus, cujo diagnóstico de anencefalia se chocou com sua sobrevida de 1 ano e oito meses. Esteve em evidência nos discursos a declaração do ministro da Saúde José Gomes Temporão colocando o aborto como problema de saúde pública. O projeto de lei do Estatuto do Nascituro despertou polêmica, por conta de diversos opositores. Foram comentados os últimos desdobramentos da ação de inconstitucionalidade (ADI 3510) contra o artigo $5^{\circ}$ da Lei de Biossegurança que autorizava a obtenção e pesquisa com células-tronco embrionárias: a audiência pública de instrução com especialista da área biomédica no STF em 2007 e o julgamento no Supremo em 2008. Foi objeto de debate em 2010 o questionamento da redação sobre aborto do $3^{\circ}$ Programa Nacional de Direitos Humanos (PNDH3), outra iniciativa do Governo Federal, que propunha sua legalização como sinal de autonomia da mulher. $\mathrm{O}$ último tema referiu-se à campanha eleitoral para a Presidência em 2010, e as especulações a respeito da posição da candidata do PT Dilma Rousseff quanto ao aborto.

Em 2007, foram localizados discursos de 40 parlamentares contendo a palavra-chave "aborto", com associação de aborto, nascituro e embrião por três parlamentares, enquanto um combinou aborto e nascituro. $\mathrm{O}$ grande destaque em termos de atuação parlamentar foi do deputado espírita Luiz 
Bassuma (PT-BA), orador de 20 pronunciamentos. Há um número bem superior de parlamentares com posições antiaborto (31), principalmente entre os religiosos: 12 católicos, 11 evangélicos ${ }^{16}$ e um espírita, porém sete deputados sem religião identificada também fizeram discursos contra o aborto. Os sete posicionamentos pró-escolha foram encontrados principalmente entre parlamentares sem religião identificada (cinco), mas também por parte de dois católicos. Os pronunciamentos de dois parlamentares - um sem religião declarada, o outro católico - não se definiam pró-vida nem pró-escolha.

Em 2008, 45 parlamentares discursaram sobre o tema do aborto, sendo que 44 usaram a palavra-chave "aborto" e um, exclusivamente embrião, mas dos 44 , dez citaram as palavras "aborto" e "embrião", dois usaram "aborto" e "nascituro", e um usou as três palavras. O grande número de menções à palavra-chave "embrião" está associado ao julgamento da ação de inconstitucionalidade contra a Lei de Biossegurança, que autorizou a pesquisa com células-tronco derivadas de embriões humanos. Destacaram-se o deputado espírita Luiz Bassuma (PT-BA) e o deputado católico (da renovação carismática) Miguel Martini (PHS-MG), ambos com 13 discursos antiaborto. No tocante ao pertencimento religioso, dos trinta parlamentares que discursaram antiaborto, 12 eram evangélicos, ${ }^{17} 12$ eram católicos, um era espírita e cinco não tinham religião identificada. Todos os dez parlamentares que fizeram pronunciamentos pró-escolha não tinham religião identificada. Quatro discursos eram indefinidos - dentre eles três foram apresentados por deputados sem religião identificada e um por católico. ${ }^{18}$

Em 2009, foram localizados 32 parlamentares com discursos abordando a temática do aborto, sendo que trinta e um deputados proferiram a palavra-chave "aborto" (dois em associação com nascituro) e um usou apenas a palavra "embrião" em seu discurso no plenário. Dos 32 parlamentares, 13 assumiram postura antiaborto. No tocante ao pertencimento religioso desses 11, quatro não tinham religião identificada, quatro eram católicos, dois eram

\footnotetext{
${ }^{16}$ Foram três da Assembleia de Deus, três da Sara Nossa Terra, um da Comunidade Shamá, um da IURD, uma da Igreja Cristã Evangélica, um batista e um presbiteriano.

${ }^{17}$ Foram oito da Assembleia de Deus, dois da Sara Nossa Terra, um presbiteriano e uma batista.

18 Um deputado sem religião identificada elogiou a CNBB pela Campanha da Fraternidade em Defesa da Vida e um deputado católico destacou a importância da celebração do Dia do Nascituro, por sua importância em defesa da vida, e ressaltando que a questão não era ser contra ou favorável à descriminalização do aborto. Ou seja, iniciativas pró-vida são elogiadas, mas os parlamentares não se dizem contra ou favoráveis à prática. Os discursos indefinidos fazem parte da retórica parlamentar de evitar se comprometer em temas polêmicos.
} 
evangélicos (um da Igreja Renascer em Cristo $^{19}$ e um do Evangelho Quadrangular) e um era espírita, ou seja, mais de um terço dos que discursaram contra o aborto eram sem religião. Nove parlamentares fizeram discurso pró-escolha, dos quais oito eram sem religião identificada e um era católico. Havia dois parlamentares com discurso indefinido, sendo um evangélico (Quadrangular) e um sem religião identificada. Essa distribuição atípica deve-se a uma polêmica que mobilizou dez parlamentares a discursar: o caso de uma menina pernambucana de nove anos grávida de gêmeos por ação de seu padrasto, menina esta que fez aborto legal, tendo suscitado a reação do arcebispo de Olinda que declarou a excomunhão da equipe médica e da mãe que autorizou a intervenção. Dez deputados se manifestaram contra a atitude do arcebispo e vários se solidarizaram com a equipe médica. Desses dez, seis não tinham pertencimento religioso identificado, três eram católicos e um era evangélico (IURD). Um deputado evangélico (Igreja do Evangelho Quadrangular) colocou ambas as possibilidades: o aborto ser traumático e a continuidade da gravidez também. O escândalo provocado pelo caso quebrou o padrão das manifestações acerca do aborto. Foi destacada a atuação do deputado espírita Luiz Bassuma (PT-BA) que proferiu nove discursos no tema, seguido pelo deputado Paes de Lira (Partido Trabalhista Cristão PTC-SP; seis pronunciamentos), sem vínculo religioso identificado, ambos de posição antiaborto.

No último ano da presidência de Lula, em 2010, vinte e um parlamentares se pronunciaram em discurso acerca do aborto, do quais vinte mencionaram a palavra "aborto" (associada a nascituro nos discursos de cinco parlamentares) e um usou apenas a palavra "nascituro". No tocante ao pertencimento religioso, dos 11 deputados que discursaram contra o aborto, quatro eram católicos, três evangélicos (um da Assembleia de Deus, um da Igreja Sara Nossa Terra e um batista), um era espírita, e três não tinham religião identificada. Nenhum dos cinco parlamentares com discursos pró-escolha tinham religião identificada. Também cinco foi o número de parlamentares cujo discurso não definia sua posição sobre aborto, sendo três católicos e dois sem religião. Esses últimos discursos defendiam a então candidata Dilma Rousseff dos ataques da imprensa com respeito à sua posição sobre $a_{b o r t o}{ }^{20}$, criticavam

\footnotetext{
${ }^{9}$ Classificada por Freston (1996) entre as neopentecostais.

20 Para uma análise do tema do aborto na campanha presidencial de 2010 ver Machado (2012) e sobre a cobertura desse tema pela mídia durante a campanha ver Luna (2011).
} 
a acusação do deputado Luiz Bassuma de que o PT expulsaria os deputados contrários à descriminalização do aborto, e um acusou de falsa uma lista de parlamentares pretensamente favoráveis ao aborto. Os destaques do ano foram os deputados Paes de Lira (PTC-SP), sem vínculo religioso identificado, autor de nove discursos antiaborto, seguido do católico de posição antiaborto Dr. Talmir (Partido Verde - PV-SP) e de José Genoíno (PT-SP), defensor da perspectiva pró-escolha, ambos autores de nove discursos.

No tocante às proposições legislativas na legislatura de 2007 e 2010, foram localizadas 57 com as palavras-chave, e em 77,2\% (44) constava o termo "aborto". A proporção dos projetos de lei aumentou em relação ao quadriênio anterior, com total de 34 em 57 dos projetos versando sobre a questão do aborto (antes eram $22 \mathrm{em} \mathrm{58).} \mathrm{Apenas} \mathrm{dois} \mathrm{projetos} \mathrm{de} \mathrm{lei} \mathrm{não} \mathrm{se}$ referiam ao problema do aborto, ou a questões associadas a gravidez e direitos do nascituro. Foram localizados sete projetos de auxílio para gestante. Entre eles estão o auxílio à mulher que tiver filho resultante de estupro e outro de orientação sobre métodos e consequências do aborto para gestante autorizada à interrupção legal de gravidez, de modo que ambos os projetos visam desestimular o aborto legal em caso de gestação resultante de violência sexual. Um projeto de alteração na CLT garante à mulher, em caso de morte do filho ou de aborto não criminoso, que não seja interrompido o direito de manter a estabilidade provisória no emprego até cinco meses após o parto. Um projeto garante uma bolsa auxílio de três meses para a gestante que fizer aborto legal em caso de estupro ou que sofrer aborto espontâneo. É notável a ambiguidade dos projetos de auxílio, que podem apresentar tanto caráter pró-vida ao persuadir a mulher a prosseguir a gestação a despeito de existir previsão legal para o aborto, quanto caráter pró-escolha, quando ampara a mulher que praticou aborto legal, sendo que os últimos estão em minoria nessa legislatura. Entre os projetos antiaborto, estão as propostas de aumento de pena para o ato (seis), a tipificação de crime de instigação ou auxílio à prática do aborto, o registro da gestação (cinco), o estabelecimento de direitos para o nascituro (11), a advertência sobre aborto nas embalagens dos testes para gravidez (um) e o serviço telefônico de denúncia de aborto clandestino (um).

No tocante aos direitos do nascituro, além do projeto que institui oito de outubro como Dia do Nascituro, o Estatuto do Nascituro (PL 478/2007, na proposta de 2007, com autoria de Luiz Bassuma e Miguel Martini) estabelece o direito inviolável à vida desde a concepção, o que inclui explicitamente 
os embriões fora do corpo da mulher concebidos para reprodução assistida na fertilização in vitro no laboratório antes da transferência para o útero ou congelados, e mesmo os fetos que não têm possibilidade de sobrevida, como os anencéfalos, conhecidos como bebês sem cérebro. $O$ estatuto prevê outros direitos civis: direito à saúde, à alimentação, à dignidade, ao respeito, à liberdade e à convivência familiar, à pensão alimentícia se concebido em ato de violência sexual, direito a receber doação, legitimidade para suceder, além de regras de proteção ao nascituro. Outros projetos propõem direitos variados, como estabelecer o estatuto de dependente no imposto de renda: direitos para o nascituro quando o vírus HIV estiver presente na gestação; quando os pais se separam; o direito do nascituro desde a fecundação de receber o seguro DPVAT (referente a acidentes de trânsito), além de incluir a defesa do nascituro e auxílio à maternidade no ECA (Estatuto da Criança e do Adolescente). Nessa legislatura, houve apenas dois projetos de lei pró-escolha, propondo a redução ou isenção da pena para aborto: um para quando há anomalia incompatível com a vida extrauterina, e outro propondo a redução da pena para o crime de aborto de três anos para dois anos.

Em 2008, destacam-se algumas proposições legislativas: projeto de emenda constitucional com estabelecimento da inviolabilidade do direito à vida para os índios e o requerimento para a criação de uma Comissão Parlamentar de Inquérito (CPI) para investigar o comércio de substâncias abortivas, que passou a ser conhecida como a CPI do Aborto, proposta retomada em 2010. Como reação, em 2010 houve um requerimento para realizar uma audiência pública para debater o aborto inseguro.

A análise dos projetos de lei da segunda legislatura do governo Lula é mais complexa. Aumenta o número de projetos que proporcionam direitos de assistência à gestante associados ao direito do nascituro. Isso sugere estratégias de controle social para afetar as decisões das mulheres em particular com respeito ao aborto legal. Foram localizados 25 projetos de lei referentes ao aborto ou a direitos do nascituro. Alguns projetos cabem em mais de uma classificação, isto é, direitos da mulher e do nascituro, ao mesmo tempo. Os projetos antiaborto estão relacionados ao aumento da penalidade ou criação de tipos penais, aos direitos do nascituro e ao controle social (o que pode incluir ou não direitos à gestante). Os projetos pró-escolha também visam aos direitos da gestante, porém com foco maior em sua pessoa, do que no nascituro, e a descriminalização e supressão de pena para aborto. Muitas vezes 
a concessão de um auxílio, caso da "bolsa estupro" (no apodo feminista), ou da inclusão dos direitos de auxílio à maternidade e do nascituro no Estatuto da Criança e do Adolescente, implica o controle da mulher. Existem os projetos de controle mais explícito como o registro público de gravidez, ou a advertência contra $o$ aborto nos testes de gravidez, ou a orientação contra o aborto nos serviços de aborto legal.

No tocante ao pertencimento religioso, dos sete parlamentares que propuseram projetos de lei de aumento da penalidade ou criação de tipos penais para o aborto, quatro são católicos, um é espírita e dois são sem religião. Salienta-se aqui a ausência de evangélicos. Já quanto aos autores de projetos que propõem medidas de controle social, cinco são católicos, e cinco evangélicos ${ }^{21}$. Os 11 projetos referentes ao direito do nascituro são de autoria de seis católicos (um projeto tem dois autores), dois evangélicos (Comunidade Shamá e Sara Nossa Terra), um espírita e dois sem religião identificada. Houve grande redução do número de projetos pró-escolha: apenas dois, sendo um de redução de pena e outro de isenção em caso de anencefalia, ambos de autores sem religião. Um projeto de prevenção à transmissão vertical do HIV beneficiaria gestante e nascituro, não se encaixando na rubrica de controle social.

Faço alguns comentários quanto à articulação com entidades religiosas externas ao Congresso e o valor da laicidade. $\mathrm{Na}$ segunda legislatura do governo Lula, no escopo dos discursos levantados com as palavras-chave "aborto", "embrião", "nascituro" e "reprodução assistida", foram encontrados 27 discursos de 14 parlamentares que fizeram menção à CNBB, todos proferidos por deputados antiaborto. Os autores dos discursos eram: sete católicos, três evangélicos (dois da Assembleia de Deus e um da Comunidade Shamá), três sem religião identificada e um espírita. A CNBB é citada: 1) no contexto da marcha contra o aborto, com ênfase na união de católicos e evangélicos (proferido por um católico e um evangélico) e dessas religiões cristãs e espíritas (deputado espírita menciona as três religiões); 2) com referência à coordenadora da Pastoral da Criança da CNBB, que indagou à Organização Panamericana de Saúde sobre dados de mortalidade materna associados ao aborto (deputado católico); 4) no contexto de crítica à dubiedade do presidente Lula quanto ao aborto, apresentando uma posição quando está com

${ }^{21}$ Foram dois da Igreja Sara Nossa Terra, um da IURD, um batista e um presbiteriano. 
a CNBB e outras conforme sua conveniência (evangélico); 5) referindo-se a eventos promovidos pela $\mathrm{CNBB}$ em relação à defesa da vida (dois católicos) ou presença de representantes da entidade nesse tipo de evento (católico); 6) quanto à instituição do Dia do Nascituro pela Conferência (um católico discursa em três anos diferentes, e outro católico em 2009); 7) em ocasião, em 2008, em que houve elogio pelo lançamento da Campanha da Fraternidade em Defesa da Vida (um espírita, dois católicos, dois sem religião); 8) na presença da CNBB juntamente com a Federação Espírita Brasileira em reuniões do Movimento Nacional Brasil sem Aborto (espírita) e da Frente Parlamentar em Defesa da Vida (deputado espírita); 9) em palestra na CNBB que iguala eficácia da pesquisa com células-tronco embrionárias humanas com as de cordão umbilical (deputado católico); 10) em abaixo-assinado contra o aborto promovido por líderes da CNBB; e 11) contra o Programa Nacional de Direitos Humanos 3 (PNDH-3) afirmando união dos evangélicos com deputados católicos e a posição da CNBB (evangélico, Assembleia de Deus). De modo geral, exceto pelo discurso de um deputado católico elogiando a união de católicos e evangélicos na luta contra o aborto, são os evangélicos que frisam a união com os católicos nessa causa, e o único deputado espírita coloca a presença de sua religião com católicos e às vezes também com evangélicos. A presença da CNBB como uma entidade das mais representativas na luta antiaborto é lembrada por deputados religiosos, principalmente católicos, mas reconhecida por evangélicos e pelo espírita e também por aqueles sem religião identificada.

No quadriênio 2007-2010, três parlamentares citaram a ONG Católicas pelo Direito de Decidir. Um parlamentar católico critica a entidade por promover o "genocídio de nascituros no mundo". Uma parlamentar católica e um parlamentar sem religião identificada mencionam a ONG como fonte de dados: a católica cita uma pesquisa do Ibope encomendada pela ONG sobre o grau de aceitação de diferentes modalidades de aborto no país (mencionada por ambos), e o sem religião identificada menciona documento da CDD que lista os direitos das mulheres, inclusive o de considerar aborto problema de saúde pública.

Quanto às formas de relação entre Estado e religião, Giumbelli (2002) considera que o modelo de separação é apenas uma das modalidades e propõe que o foco analítico seja na relação. A definição de Estado laico diz respeito à separação entre Estado e religião. Esse tema do Estado laico aparece mais 
vezes nessa legislatura: a palavra "laico" é mencionada em 18 discursos de 13 deputados. O deputado José Genoíno (PT) faz o maior número de discursos (5). Dos 13 deputados, seis têm posições antiaborto (quatro evangélicos, sendo dois batistas e dois assembleianos, e dois católicos), e sete têm posição pró-escolha (dois católicos e cinco sem religião declarada). Não se constata divisão linear com oposição entre religiosos antiaborto e não religiosos pró-escolha. Favoráveis e contrários à legalização do aborto abordam o problema do Estado laico. Religiosos e não religiosos usam esse argumento. Os parlamentares de posição pró-escolha comentaram os limites que um Estado laico coloca às práticas religiosas e à transformação dessas crenças em lei civil: um deputado se solidarizou com a equipe médica (que realizou o aborto) no caso da menina pernambucana que engravidou de gêmeos do padrasto; houve crítica a se impor um projeto como o Estatuto do Nascituro em um Estado laico; debateu-se o direito ao aborto e sua perspectiva como problema de saúde pública; e pediu-se o registro em ata de documentos sobre direitos reprodutivos e o Estado laico. Quanto aos religiosos com posição pró-escolha, um parlamentar que se disse católico praticante afirma que um Estado laico tem que garantir as opções ao aborto dentro do limite da lei, enquanto outra parlamentar católica elogiou no caso de menina pernambucana ter sido dado o tratamento condizente com a legislação brasileira à vítima e a sua família, enquanto um deputado evangélico (bispo da IURD) criticou a excomunhão da mãe da menina pernambucana.

Outras questões foram associadas ao Estado laico por deputados religiosos de posição antiaborto. Um deputado católico faz a proposta de plebiscito sobre aborto, já que o Estado é laico. Vários relativizam o sentido de Estado laico em função de outros valores: a formação religiosa da população e o respeito à vida. Nesse sentido, um deputado católico afirma que o Estado não pode ser considerado simplesmente laico, porque "tem berço cristão", enquanto um deputado evangélico (assembleiano) afirma que o respeito à vida humana é um "imperativo categórico" acima do Estado laico. Ainda no tocante ao respeito à vida, uma deputada evangélica (batista) descarta que o problema seja o Estado laico, mas sim a consciência e não a religião que define algo como crime. Além da liberdade de consciência, o Estado laico é também associado à liberdade religiosa e de palavra: um evangélico (batista) definiu o Brasil como "país laico, onde a liberdade religiosa é assegurada". Algumas vezes a ambiguidade é notória: o pastor Pedro Ribeiro declarou 
ter o direito à palavra assegurado pelo Estado laico para afirmar que Deus é "o senhor da vida"

\section{Considerações finais}

Os temas debatidos em ambas as legislaturas revelam que fazem parte da controvérsia do aborto (Giumbelli, 2002) elementos internos ao Congresso Nacional - como a Lei de Biossegurança, trazendo a pesquisa com células-tronco embrionárias -, mas também elementos de outras instituições da sociedade, como o SUS ao emitir uma norma técnica para atenção humanizada ao aborto, o STF ao considerar além da própria Lei de Biossegurança a possibilidade de antecipação de parto de anencéfalo - ponto último que o Congresso Nacional não conseguiu apreciar até o momento. Também integram a controvérsia atos referentes ao Executivo, como o PNDH3 e sua proposta de legalização, a comissão Tripartite que propôs a revisão da legislação punitiva, e declarações do ministro da Saúde de ser o aborto um problema de saúde pública. O caráter clandestino do aborto aparece nos comentários sobre o indiciamento de usuárias de clínica em Mato Grosso por suspeita dessa prática e denúncias do uso de substâncias abortivas que suscitaram os parlamentares antiaborto a solicitar uma CPI. A sobrevivência da menina Marcela de Jesus com diagnóstico de anencefalia também foi usada na argumentação. O aborto previsto em lei causa comoção. É o caso da menina pernambucana que engravidou do próprio padrasto e o ato de excomunhão pelo bispo de Olinda. O último ponto do período é a discussão do tema do aborto na campanha presidencial.

Se as representações mais visíveis dessa controvérsia são de posições polarizadas, no presente levantamento documental foi encontrada quantidade significativa de discursos e projetos de lei indefinidos, que fogem da polarização pró-vida e pró-escolha. No tocante ao pertencimento religioso, se é óbvio o protagonismo dos parlamentares religiosos no movimento pró-vida, os deputados sem religião identificada se dividem igualmente entre posições antiaborto e pró-escolha. Isso sugere que a resistência à descriminalização do aborto no Brasil ultrapassa o pertencimento religioso explícito. Foram observados alguns parlamentares com atuação sistemática pró-vida sem constatação de vínculo religioso. Verificou-se entre a primeira e a segunda legislaturas uma redução da militância pró-escolha no debate parlamentar, considerando o número de projetos voltados para a descriminalização do 
aborto e de discursos com essa orientação. O cerne da controvérsia é a existência ou não do direito à vida pelo feto, contraposto ao direito de a mulher decidir sobre seu corpo e a gestação em curso. Contudo, além da definição do feto ou embrião como um ser humano pleno, conforme faz o Estatuto do Nascituro, novos direitos são reivindicados para o feto em projetos que lhe concedem cidadania: inclusão como dependente no imposto de renda, e direito ao seguro por acidentes de trânsito, entre outros. A estratégia do movimento antiaborto não se detém nos direitos do nascituro, mas busca propiciar benefícios à gestante para evitar que ela recorra à interrupção da gravidez, além de criar formas explícitas de controle social, como o registro de gravidez. Na justificativa desses projetos, está presente a defesa da vida.

Estudos sobre o debate parlamentar no Brasil, Argentina e Uruguai associam os religiosos com os integrantes do movimento pró-vida, fazendo resistência à legalização do aborto (Rocha, Rostagnol e Gutiérrez, 2009; Rostagnol, 2008). Se o presente artigo reconhece o protagonismo dos agentes religiosos na discussão no Congresso Nacional do Brasil nas duas legislaturas do governo Lula, o cuidado na identificação dos autores de discursos e proposições legislativas revela uma diversidade que impede considerar os religiosos como um ator social monolítico nesse debate. Constata-se diversidade na composição do que seria a bancada evangélica, o que já foi assinalado por estudos de Machado (2006) e Campos (2006), com protagonismo dos pentecostais e neopentecostais, que representam também a maior proporção de evangélicos no Brasil, conforme demonstram os dados dos censos de 2000 e de 2010 (IBGE, 2012), e a participação mais discreta e numericamente menor dos protestantes históricos. ${ }^{22}$

A controvérsia sobre o aborto mostra alianças entre católicos, evangélicos e espíritas no movimento antiaborto; por outro lado, verificam-se diferenças de posição entre eles: deputados evangélicos ligados à Igreja Universal do Reino de Deus se posicionaram a favor do aborto em caso de anencefalia e na situação de menina pernambucana, ou justificaram sua posição favorável à pesquisa com células-tronco embrionárias humanas argumentando em termos de um Estado laico ${ }^{23}$. Já os assembleianos mantiveram-se em posição

\footnotetext{
22 Com respeito às diferenças internas, no tocante aos católicos, um aspecto não explorado neste artigo foi a participação de políticos ligados à Renovação Carismática, embora alguns tenham sido identificados.

23 A posição desses deputados não foi tão liberal e pró-escolha como a exposta pelo líder da IURD, bispo Edir Macedo, que admite a interrupção da gravidez em diversas circunstâncias (Gomes, 2009).
} 
antiaborto em todos os exemplos levantados. Parlamentares sem religião se alinham tanto do lado pró-vida como do lado pró-escolha. Se a CNBB é um ator social influente, conforme se constata em sua presença nos discursos, a ONG Católicas pelo Direito de Decidir também é citada como alternativa no campo católico em termos acusativos pelo movimento antiaborto, e pelos pró-escolha como fonte de informações que afetam o debate. Individualmente, alguns parlamentares católicos criticaram a posição da Igreja, ou de seus representantes, em particular no caso da menina pernambucana que engravidou de gêmeos, pela postura do arcebispo de Olinda em declarar a excomunhão automática da equipe médica que realizou o aborto e da mãe dela, que autorizou o procedimento.

Dworkin (2003) assinala a emergência do movimento pró-vida após a legalização do aborto nos Estados Unidos em 1973. A partir do exame do material legislativo levantado e da inserção dos parlamentares, ainda não é possível falar que se trata de lobistas do movimento antiaborto no Brasil. A ONG Brasil sem Aborto foi criada em 2008, após o Supremo Tribunal Federal ter considerado constitucional o artigo da Lei de Biossegurança que autorizou a pesquisa com células-tronco embrionárias. Trata-se, assim, antes, de parlamentares de orientação antiaborto, muitos dos quais - embora nem todos - têm vínculo religioso identificado.

Nesse debate, percebe-se o choque entre valores holistas e individualistas (Dumont, 1997) ${ }^{24}$, mas também sua convivência estreita. Os valores holistas estariam representados na defesa da vida sagrada que é dom de Deus (Machado, 2010). O princípio da laicidade do Estado, invocado como conquista da modernidade ocidental (cf. Giumbelli, 2002) ${ }^{25}$, se contrapõe a tal argumen-

${ }^{24}$ Dumont opõe duas configurações de valores que caracterizam as sociedades tradicionais e a sociedade moderna. Nas sociedades tradicionais, de configuração holista de valores, o acento está sobre a sociedade como um conjunto, como o ser humano coletivo, e o ideal é a organização da sociedade em vista de seus fins; trata-se de ordem, de hierarquia. Nas sociedades modernas, de configuração individualista, o ser humano é elementar, indivisível na forma de ser biológico e de sujeito pensante. Cada ser humano encarna a humanidade inteira e é a medida de todas as coisas. A sociedade é o meio e a vida de cada um é o fim (Dumont, 1997, p. 57).

25 Tanto Giumbelli (2002) como Montero (2009) questionam a tese da secularização como conquista da modernidade ocidental, que, ao separar Estado e religião, teria isolado a religião em um compartimento privado, quando, em uma perspectiva evolucionista, antes a religião se referia à totalidade da vida social. Giumbelli nega que religião constitua um domínio autônomo da sociedade e remete a análise à relação de religião e modernidade."Modernidade e religião cultivam uma relação positiva entre si: a modernidade construindo e dependendo de uma certa concepção de religião e a religião mantendo-se como um domínio que revela muito sobre a sociedade que a engendra"(Giumbelli, 2002, p. 24). Assim permanecem tensões entre o ideal de laicidade e os valores religiosos na gestão da vida do país (Duarte et al., 2009). 
tação, por um lado. Por outro, os valores individualistas se manifestam na defesa da autonomia feminina, pois na perspectiva feminista a mulher tem o direito de decidir sobre o próprio corpo e o desenvolvimento da gestação. Contudo os valores individualistas também se manifestam quando se identifica o embrião ou feto como um sujeito dotado de direitos, um indivíduo desprovido de relações que está inserido em um meio (o útero) para se desenvolver. Como se trata de uma relação hierárquica entre a mulher grávida e o feto, na perspectiva feminista e pró-escolha, a mulher engloba o feto e tem precedência sobre ele. Já na perspectiva pró-vida ou antiaborto, o feto engloba a mulher, que é encarada como suporte para seu desenvolvimento e não pode optar por interromper a gravidez, pois a vida sagrada é uma totalidade maior do que ela (cf. Dumont, 1997; Dworkin, 2003). Dworkin afirma que a questão principal no debate público sobre o aborto diz respeito a ambos os lados considerarem a sacralidade da vida humana, sendo que o lado pró-escolha vai enfatizar a vida da mulher, em contraste com a perspectiva pró-vida, centrada na proteção do feto. Dworkin demonstra a partir de vários exemplos da controvérsia que o cerne no debate é a sacralidade da vida humana e não a definição sobre se o embrião humano é uma pessoa dotada de direitos, inclusive o direito à vida. Esses resultados corroboram as conclusões de Machado (2010) ao comparar o debate sobre aborto na França e no Brasil, descrevendo como a autonomia feminina foi central no debate francês, enquanto o argumento de defesa da vida, secundário naquele país, aparece de modo fundamental no brasileiro. No Brasil, a polêmica sobre o aborto se centra no feto, enquanto a mulher surge secundariamente como uma vítima das circunstâncias que a levaram a engravidar ou uma vítima de seus próprios atos para terminar uma gravidez indesejada. Os diversos projetos de lei com medidas de controle social para evitar que a mulher pratique o aborto nos casos permitidos por lei são exemplos que demonstram a recusa por certos grupos sociais da possibilidade de autonomia feminina.

É surpreendente também o modo como se aciona o argumento do Estado laico. Em um contexto em que há mais vozes antiaborto do que pró-escolha, mais parlamentares antiaborto falaram do Estado laico, exemplo da primeira legislatura do governo Lula. Se parlamentares sem religião de posição pró-escolha mencionaram o Estado laico para criticar a interferência de valores religiosos na esfera civil, houve alguns parlamentares religiosos tanto de orientação pró-escolha como antiaborto que defenderam o Estado laico em 
termos de um espaço para liberdade de consciência e pluralidade de posições, inclusive as religiosas. Se vários parlamentares antiaborto afirmaram que existe um valor holístico maior que o Estado laico, no caso, a defesa da vida, houve um pastor com esse mesmo posicionamento que justificou a oportunidade dada pelo Estado laico de se manifestar para afirmar o valor holístico - "Deus é o senhor da vida" -, o que ressalta as ambiguidades e tensões entre esses valores. Se, no final do século XX, a inserção de religiosos na política, em particular os ligados à vertente progressista da Igreja Católica enfatizava a luta por direitos humanos no sentido de direitos sociais, quando se verificam os discursos e proposições legislativas na Câmara dos Deputados, percebe-se que a luta por direitos humanos é ressignificada por direito à vida e por liberdade religiosa. Ressalta-se que o argumento da liberdade de expressão religiosa em um Estado laico é apropriado tanto por evangélicos como por católicos no presente debate.

A presença de valores e atores religiosos na esfera pública é feita em um processo que comporta diversas tensões e contradições e não confirma uma perspectiva da secularização como redução linear da presença do religioso no mundo. Segundo Montero (2009), as sociedades modernas impõem a convivência de uma pluralidade de visões de mundo e formas de vida no mesmo espaço político, o que inclui as religiões nas dinâmicas simbólicas. O presente artigo buscou captar a pluralidade desse debate e seus matizes, fugindo das oposições simplistas. O religioso não está confinado ao privado com a modernidade (cf. Berger, 1985), segundo uma interpretação consagrada da teoria da secularização, mas, conforme sugerem as pesquisas de Montero (2009) e Giumbelli (2002), é fundamental investigar sua articulação com o domínio da política e suas reconfigurações a partir da atuação de diferentes sujeitos religiosos.

\section{Referências}

BERGER, Peter L. (1985). O dossel sagrado: elementos para uma teoria sociológica da religião. São Paulo: Paulus.

BIRMAN, Patrícia \& LEITE, Márcia Pereira (2002). "O que aconteceu com o antigo maior país católico do mundo?”, em BETHEL, Leslie (org.). Brasil: fardo do passado, promess a do futuro. Rio de Janeiro: Civilização Brasileira.

CAMPOS, Leonildo Silveira (2006). "Os políticos de Cristo: uma análise do comportamento político de protestantes históricos e pentecostais 
no Brasil", em BURITY, Joanildo A. \& MACHADO, Maria das Dores Campos (orgs.). Os votos de Deus: evangélicos, política e eleições no Brasil. Recife: Massangana.

DUARTE, Luiz Fernando Dias et al. (orgs.) (2009). Valores religiosos e legislação no Brasil: a tramitação de projetos de lei sobre temas morais controversos. Rio de Janeiro: Garamond, FAPERJ.

DUMONT, Louis (1997). Homo hierarchicus: o sistema de castas e suas implicações. São Paulo: Edusp.

DWORKIN, Ronald (2003). Domínio da vida: aborto, eutanásia e liberdades individuais. São Paulo: Martins Fontes.

FRESTON, Paul (1996). "Breve história do pentecostalismo brasileiro", em ANTONIAZZI, Alberto et al. (orgs.). Nem anjos nem demônios. Petrópolis: Vozes.

GIUMBELLI, Emerson (2002). O fim da religião: dilemas da liberdade religiosa no Brasil e na França. São Paulo: Attar.

GOMES, Edlaine de Campos (2009). “Fé racional' e 'abundância': família e aborto a partir da ótica da Igreja Universal do Reino de Deus". Sexualidad, Salud y Sociedad - Revista Latinoamericana, n. 2, p. 97-120.

IBGE (Instituto Brasileiro de Geografia e Estatística) (2012). "Censo 2010: número de católicos cai e aumenta o de evangélicos, espíritas e sem religião". Sala de imprensa: Censo demográfico de 2010-características gerais da população, religião e pessoas com deficiência. Disponível em: http://www.ibge.gov.br/home/presidencia/noticias/noticia_visualiza. php?id_noticia=2170. Acessado em 14 fev. 2013.

JACOB, Cesar Romero et al. (2003). Atlas da filiação religiosa e indicadores sociais do Brasil. Rio de Janeiro: Editora PUC-Rio; São Paulo: Loyola.

LEITE, Márcia Pereira (2003). "Novas relações entre identidade religiosa e participação política no Rio de Janeiro hoje: o caso do movimento popular de favelas", em BIRMAN, Patrícia (org.). Religião e espaço público. Attar: São Paulo

LUNA, Naara (2010). "A polêmica do aborto e o $3^{\circ}$ Programa Nacional de Direitos Humanos". Trabalho apresentado no $34^{\circ}$ Encontro Anual da ANPOCS. Caxambu, 25 a 29 de outubro.

LUNA, Naara (2011). "A polêmica do aborto na campanha eleitoral de 2010: um estudo sobre representações na imprensa". Trabalho apresentado na IX Reunião de Antropologia do Mercosul. Curitiba, 10 a 13 de julho. 
MACHADO, Lia Zanotta (2010). Feminismo em movimento. São Paulo: Francis.

MACHADO, Maria das Dores C. (2000). “O tema do aborto na mídia pentecostal”. Estudos Feministas, v. 8, n. 1, p. 211-223.

(2006). Política e religião: a participação dos evangélicos nas eleições. Rio de Janeiro: Editora FGV.

(2012). “Aborto e ativismo religioso nas eleições de 2010”. Revista Brasileira de Ciência Política, n. 7, p. 25-54.

MAFRA, Clara (2001). Os evangélicos. Jorge Zahar: Rio de Janeiro.

MONTERO, Paula (2009). "Jürgen Habermas: religião, diversidade cultural e publicidade”. Novos Estudos CEBRAP, n. 84, p. 199-213.

ORO, Ari Pedro (2003). "A política da Igreja Universal e seus reflexos nos campos religioso e político brasileiros". Revista Brasileira de Ciências Sociais, v. 17, n. 53, p. 53-69.

ROCHA, Maria Isabel Baltar da \& ANDALAFT NETO, Jorge (2003). "A questão do aborto: aspectos clínicos, legislativos e políticos", em BERQUÓ, Elza (org.). Sexo \& vida: panorama da saúde reprodutiva no Brasil. Campinas: Editora da Unicamp.

ROCHA, Maria Isabel Baltar da; ROSTAGNOL, Susana \& GUTIÉRREZ, María Alicia (2009). "Aborto y Parlamento: un estúdio sobre Brasil, Uruguay y Argentina”. Revista Brasileira de Estudos Populacionais, v. 26, n. 2, p. 219-236.

ROSTAGNOL, Susana (2008). "El conflicto mujer-embrión en debate parlamentario sobre el aborto". Estudos Feministas, v. 16, n. 2, p. 667-674.

\section{Resumo}

O artigo analisa o debate sobre aborto na Câmara dos Deputados durante as duas legislaturas do governo Lula (2003-2006; 2007-2010) considerando o embate entre as posições pró-vida e pró-escolha. O material examinado são discursos e proposições legislativas. Esta pesquisa demonstra um quadro diversificado. Observam-se alianças entre feministas e religiosos, e políticos de pertencimento religioso declarado se opõem às diretrizes de sua instituição. $O$ debate sobre o direito à vida será o foco de análise nessa controvérsia, contraposto às reivindicações de autonomia da mulher. Além da interferência da Igreja Católica, os evangélicos surgem como atores privilegiados articulados na Frente Parlamentar Evangélica. A defesa do Estado laico é argumento usado por ambos os lados para garantir a pluralidade de posições no espaço público.

Palavras-chave: aborto; debate legislativo; religião; Congresso Nacional; antropologia. 


\section{Abstract}

The article analyses the debate on abortion at the Chamber of Deputies during President Lula's first and second terms (2003-2006; 2007-2010), considering pro-life and pro-choice positions. It examines discourses and law propositions and the result is a diversified picture. There are alliances between feminists and clergy, and religious politicians opposing their institutions' guidelines. The focus will be on the right to life in contrast to claims of women's autonomy. Besides Catholic Church interference, Evangelical politicians come as main actors organized within the Evangelical Parliamentary Group. The defense of a Laic State is an argument used by both sides to guarantee plurality of stances in public space. Keywords: abortion; legislative debate; religion; National Congress (Brazil); anthropology.

Recebido em 31 de janeiro de 2014.

Aprovado em 4 de abril de 2014. 